\title{
OBITUARY
}

\section{Piet van Duijn}

\author{
Ton Raap · Hans Tanke
}

Published online: 7 September 2007

(C) Springer-Verlag 2007

Piet van Duijn, one of the pioneers and founders of European Cytochemistry of the twentieth century deceased on 21 June 2007 at the age of 84 .

Born in a family of fruit and crop growers, it was soon clear that Piet's intellectual gifts predestined him to a scientific, not an agricultural career. Following his chemistry study at the Free University of Amsterdam he became Head of the Biochemistry Section of the Laboratory for Pathology of the Medical Faculty of Leiden University (now the Leiden University Medical Center). Drawing from his broad scientific interests, he combined principles of chemistry, optics and physics to better understand the workings of the healthy and sick cell and to bring more objectivity in histo- and cytopathological diagnosis. Like many of us he employed the light microscope, that intriguing instrument that so neatly symbolized his beloved biomedical research. In later years, he founded his own research group: the Department of Histo- and Cytochemistry. As logo it had a test tube combined with a microscope: Piet's research could not be symbolized more powerfully.

He has been active in histo- and cytochemistry for nearly four decades and throughout he was a true scholar. The department was often referred to as Piet van Duijn's Dutch School of Histo-and Cytochemistry. His friend and colleague, the late Tony Pearse, in a Special Issue of Histochemistry and Cell Biology dedicated to Dr. van Duijn on the occasion of his retirement in 1986, refers to this as the most important feature of his career. Piet must have real-

T. Raap $(\bowtie) \cdot$ H. Tanke

Department of Molecular Cell Biology,

Leiden University Medical Center,

Leiden, The Netherlands

e-mail: A.K.Raap@lumc.nl ized this, but being a modest personality with no vanity, he never expressed pride on this scholarly feat.

Realizing the enormous chemical complexity of cells and tissues, he often took the reductionistic approach and resorted to matrix model systems incorporating the targeted macromolecules to define the specificity and stoichiometry parameters of their cytochemical reactions. Thus, major contributions have been made by him to quantitative DNA, enzyme- and immunocytochemistry.

During his long academic career, he never lost passion for science and was always on the pioneering side. As an example, he contributed to the DNA constancy theory by showing with the aid of his pioneering and thoroughly validated DNA cytometry that the "metabolic" DNA theory was built on results of methodologically flawed experiments. His greatest histochemical achievement came towards the end of his career. In the early 1980s after years of model system work and great perseverance, he established the fluorescence in situ hybridization technique, the concepts of which he already proposed in 1973. It opened up the now blooming field of molecular cytogenetics. He coined the technique Hybridocytochemistry by analogy with Immunocytochemistry, but international scientific competitors called it FISH, an acronym that somewhat to Piet's dismay was soon universally accepted.

His national and international contributions did not remain unnoticed. He was appointed associate professor in 1960 and as full professor in 1967 (chair: "Histochemistry"). In 1960 he was one of the co-founder of the International Federation of Societies for Histochemistry and Cytochemistry, for which he served as secretary-general from 1972 to 1976 and as president from 1976 to 1980 . He was elected honorary member of the American Association of Anatomists (1981), of the Polish Society for Histo- and Cytochemistry (1983), of Hungarian Society for Histology 
and Embryology (1985), and received the Pioneering Award from the Histochemical Society of the USA in 1988. He played a major role in the editorial boards of the Journal of Histochemistry and Cytochemistry (USA), Histochemistry (Germany), The Histochemical Journal (UK), and Basic and Applied Histochemistry (Italy). Piet did not easily show pride on his achievements, but one could tell he was very content with his memberhip as of 1981 of the Royal Dutch Academy of Sciences.

Discussions with him were fun, interesting and intense. Many subjects were discussed. Invariably he showed his sharp mind, fast knowledge, great memory and broad interest. Study design, experimental set-ups and pitfalls, interpretation of results and how to write a readable article were of course among the subjects discussed, but there was also plenty of time to talk about things such as serendipity and politics in science and last but not least how science, technology and religion interact to shape our society.

Indeed, he was active well across the borders of the histochemical science. His inaugural lecture in 1968 ignored Histochemistry, but instead discussed the concepts of a concentric university model. Stimulated by his strong religious background he tirelessly enforced societal discussions about ethical issues, science and religious dogmas and on the impact of biomedical technology on society.

In the daily lab life Piet was an amiable and wise man, paying attention to all of his co-workers. At the right moment in their careers he would give them the collegial, friendly or fatherly advice so as to put them on the track of independence.

As holds for the many that have known him, we will keep Piet van Duijn in our memories with good thoughts. 